\title{
Privatization and Regulation of Transport Infrastructure in the 1990s
}

Antonio Estache

Although the link between improved infrastructure services and economic growth is uncertain, it is clear that reforms aimed at creating competition and regulating natural monopolies establish an environment conducive to private sector participation, incentives for companies to strive for efficiency savings that can ultimately be passed on to consumers, and greater provision of services (such as faster roll-out of infrastructure or innovative solutions to service delivery for customers not connected to an existing network). In determining the form that infrastructure restructuring might undertake or the design of a regulatory agency, policymakers can generally benefit from a review of the experiences of other countries. A key element of any decisionmaking process should be a review of how the various types of reform will affect the efficiency of the sector and whether they will increase private financing of its significant investment needs.

Until the 1990s most forms of transport infrastructure were owned and operated by public monopolies or were closely supervised by central governments. A widespread shift in thinking about the appropriate role of the state in the marketplace took place in the 1990s, while dismay with the quality of service provided by many state-controlled public monopolies led to demands for greater efficiency and competition. Within the transport sector, the main force propelling governments to reform was fiscal crisis. Pragmatic governments, confronted with the need to cut public expenditures, were forced to turn to the private sector for assistance in financing the tremendous investments needed to modernize transportation services and infrastructure. The amounts required in developing countries were equivalent, on average, to 4-6 percent of gross domestic product (GDP) a year. Removing this burden on the economy freed up shrinking resources that could be devoted to financing deficits, servicing debts, and, in principle, supporting underfunded activities, such as education and health (although there is no strong evidence that such support has actually taken place).

Increased private sector involvement in transport infrastructure does not mean that the state has no role in these activities. Governments still have to define 
policies and strategies for the sector and finance socially valuable projects that are too risky to attract private investment at viable rates of return. But the main challenge facing governments is to make the transition from self-regulated providers of transport services to independent regulators of activities delivered by private transport operators. This new role is important because not every transport activity is competitive. In fact, transport restructuring often creates local monopolies or oligopolies. Moreover, even when competition works because entry is feasible and desirable, public regulation of safety or the quality of service is often needed to ensure that operators do not jeopardize consumers by, say, neglecting maintenance or limiting service to cut costs. Recent experience suggests that although the transfer of operations from public to private hands may be reasonably smooth, the regulatory transition is proving to be much more challenging than anticipated. In many countries the government must still make significant adjustments in its ability to regulate private suppliers to ensure that the expected efficiency and financing payoffs of private sector participation can be sustained.

This article looks at the extent of and reasons for privatization of the transport sector over the last 15 years. It reviews the most common methods governments have used to effect privatizations and the problems that governments have encountered in shifting from actively providing transportation services to regulating that provision by private entrepreneurs.

\section{Private Participation in Transport Infrastructure}

A useful - but imperfect - indicator of the trend toward private participation in transportation is the number of new transport infrastructure projects the private sector has considered since 1985. Because this number has a great deal to do with developments in local and international capital markets, it is not clear what share of investment is stimulated by privatization and what share by deregulation. Moreover, a strict comparison of numbers across sectors is quite a challenge because, for example, far more roads are built than railways.

Despite these limitations the data provide at least a rough idea of developments in the sector. Between 1985 and October 1999, an international survey (Public Works Financing International 1999) estimated that 1,006 new transport projects worth $\$ 575$ billion were being planned or financed—or both—around the world. ${ }^{1}$ About half of the projects were toll roads, a quarter involved railways, and the rest were airports and seaports. An interesting detail is that less than a third of these projects were under construction at the end of 1999, suggesting that deregulation can generate enthusiasm but does not guarantee that the private sector will follow through on planned projects. A more detailed look at the differences between industrial and developing economies provides useful insights. 


\section{Industrial Economies}

Table 1 shows that industrial countries generated less than 30 percent of the planned privatization projects in the transport sector between 1985 and 1999 but accounted for about 46 percent of the total value of planned projects around the world. This sample suggests that the average project in industrial countries is much larger than that in developing countries, which account for roughly 70 percent of the planned projects but only 54 percent of the total dollar amount.

The data show that the pattern of private infrastructure provision pioneered by the United States found followers not only in the United Kingdom-the most active project generator - but also in Australia, where national and subnational deregula-

Table 1. Projects Planned in Industrial Economies 1985- October 1998 (millions of US\$)

\begin{tabular}{|c|c|c|c|c|c|c|c|c|c|c|}
\hline \multirow[b]{2}{*}{ Country } & \multicolumn{2}{|c|}{ Toll roads } & \multicolumn{2}{|c|}{ Rail projects } & \multicolumn{2}{|c|}{ Airports } & \multicolumn{2}{|c|}{ Seaports } & \multicolumn{2}{|c|}{ Total } \\
\hline & No. & Value & No. & Value & No. & Value & No. & Value & No. & Value \\
\hline North America & 40 & 15,866 & 16 & 27,939 & 27 & 5,800 & 3 & 1,315 & 86 & 50,920 \\
\hline Canada & 10 & 4,450 & 3 & 8,016 & 3 & 1,750 & 0 & 0 & 16 & 14,216 \\
\hline United States & 30 & 11,416 & 13 & 19,923 & 24 & 4,050 & 3 & 1,315 & 70 & 36,704 \\
\hline Western Europe & 70 & 61,334 & 68 & 80,237 & 12 & 10,905 & 3 & 111 & 153 & 152,587 \\
\hline Belgium & 1 & 430 & 0 & 0 & 0 & 0 & 0 & 0 & 1 & 430 \\
\hline Denmark & 1 & 2,700 & 2 & 805 & & 0 & 0 & 0 & 3 & 3,505 \\
\hline Finland & 1 & 255 & 0 & 0 & 0 & 0 & 0 & 0 & 1 & 255 \\
\hline France & 4 & 8,121 & 4 & 2,146 & 0 & 0 & 0 & 0 & 8 & 10,267 \\
\hline Germany & 7 & 6,594 & 3 & 5,597 & 2 & 4,707 & 0 & 0 & 12 & 16,898 \\
\hline Greece & 4 & 6,874 & 1 & 547 & 4 & 3,442 & 0 & 0 & 9 & 10,863 \\
\hline Ireland & 2 & 52 & 1 & 70 & 1 & 170 & 0 & 0 & 4 & 292 \\
\hline Italy & 0 & 0 & 3 & 18,000 & 0 & 0 & 0 & 0 & 3 & 18,000 \\
\hline Netherlands & 0 & 0 & 1 & 1,580 & 0 & 0 & 0 & 0 & 1 & 1,580 \\
\hline Portugal & 10 & 6,659 & 3 & 3,185 & 1 & 2,000 & 0 & 0 & 14 & 11,844 \\
\hline Spain & 22 & 8,315 & 3 & 5,163 & 0 & 0 & 2 & 64 & 27 & 13,542 \\
\hline Sweden & 0 & 0 & 3 & 750 & 0 & 0 & 0 & 0 & 3 & 750 \\
\hline Switzerland & 0 & 0 & 1 & 12,500 & 0 & 0 & 0 & 0 & 1 & 12,500 \\
\hline United Kingdom & 18 & 21,334 & 43 & 29,894 & 4 & 586 & 1 & 47 & 66 & 51,861 \\
\hline Asia & 10 & 18,944 & 23 & 12,264 & 14 & 33,079 & 2 & 170 & 49 & 64,457 \\
\hline Australia & 9 & 4,544 & 22 & 12,110 & 11 & 4,463 & 4 & 170 & 42 & 21,287 \\
\hline Japan & 1 & 14,400 & 0 & 0 & 2 & 28,400 & 0 & 0 & 3 & 42,800 \\
\hline New Zealand & 0 & 0 & 1 & 154 & 1 & 216 & 0 & 0 & 2 & 370 \\
\hline Total & 120 & 96,144 & 107 & 120,440 & 53 & 49,784 & 8 & 1,566 & 288 & 267,934 \\
\hline Worldwide total & 448 & 212,009 & 274 & 227,808 & 165 & 103,648 & 119 & 31,895 & 1,006 & 575,360 \\
\hline
\end{tabular}

Source: Adapted from Public Works Financing (1999). 
tion has resulted in a large number of new private initiatives. Deregulation in several European countries has generated many new private rail and road projects, and a push by the European Economic Community to liberalize the sector is expected to stimulate similar projects in the rest of Europe.

\section{Developing Economies}

Table 2 summarizes a database compiled by the World Bank's Private Participation in Infrastructure (PPI) group, which tracks projects in developing countries that reached financial closure between 1990 and 1997. The database draws on various sources, including the World Wide Web, commercial databases, specialized publications, project developers and sponsors, and regulatory agencies. Unlike the database used to compile table 1, the PPI database covers actual (rather than planned) projects in transport that directly or indirectly serve the public. These projects include all divestitures, concessions (under which a private entity leases the assets and agrees to invest during the period of the contract), franchises, and operation and maintenance contracts (which award the right to operate and maintain the facility for a specified period) during the years that accounted for most of the activity in developing and transition economies shown in table 2 .

Table 2. Number of Divestitures, Concessions Contracts, Operation and Maintenance Contracts, and Investment Commitments in Developing and Transition Economies (1990-1997)

(in millions of dollars)

\begin{tabular}{|c|c|c|c|c|c|c|c|}
\hline Project & Africa & East Asia & $\begin{array}{l}\text { Eastern } \\
\text { Europe }\end{array}$ & $\begin{array}{c}\text { Latin } \\
\text { America }\end{array}$ & $\begin{array}{l}\text { Middle } \\
\text { East }\end{array}$ & South Asia & Total \\
\hline \multicolumn{8}{|l|}{ Airport } \\
\hline Number of transactions & 3 & 5 & 5 & 11 & 0 & 1 & 25 \\
\hline Value & 58.8 & $2,597.4$ & 694.1 & 388.3 & 0 & 125 & $3,863.6$ \\
\hline \multicolumn{8}{|l|}{ Port } \\
\hline Number of transactions & 3 & 36 & 3 & 36 & 5 & 7 & 90 \\
\hline Value & 0 & $5,086.2$ & 0 & $1,704.9$ & 370.5 & 833.1 & $7,994.7$ \\
\hline \multicolumn{8}{|l|}{ Rail } \\
\hline Number of transactions & 3 & 7 & 1 & 26 & 0 & 0 & 37 \\
\hline Value & 0 & $7,483.3$ & 0 & $6,208.1$ & 0 & 0 & $13,691.4$ \\
\hline \multicolumn{8}{|l|}{ Road } \\
\hline Number of transactions & 5 & 102 & 2 & 93 & 0 & 6 & 208 \\
\hline Value & 426 & 18,567 & 1,086 & $18,794.8$ & 0 & 63.5 & $38,937.3$ \\
\hline \multicolumn{8}{|l|}{ Total } \\
\hline Number of transactions & 14 & 150 & 11 & 166 & 5 & 14 & 360 \\
\hline Value & 484.8 & $33,733.9$ & $1,780.1$ & $27,096.1$ & 370.5 & $1,021.6$ & 64,487 \\
\hline
\end{tabular}

Source: World Bank PPI database; for more information on this database contact sminovj@worldbank.org. 
The PPI database deals exclusively with projects in which the private company (or a foreign state-owned company, such as Electricite de France) assumes the operating risk (or the development and operating risk) during the contract period. The database records investments and privatization revenues on a commitment basis in the year of financial closure (for which data are typically readily available). Where privatizations and new investment commitments were phased in and data were available at financial closure, they are recorded in phases. Actual disbursements have not been tracked. The values listed in table 2 show that between 1990 and 1997 private operators had committed themselves to invest about $\$ 65$ billion in transport infrastructure in the short to medium run-about 1 percent of the 1997 GDP of developing countries.

Partnerships between the government and private sector, based on strong mutual commitments, can be significant sources of financing for transport investment, particularly in areas and activities where demand is strong, thus reducing commercial risk. That is illustrated by the number of projects and the value of new investments in Latin America and East Asia, where transport reform was coupled with macroeconomic adjustments. Indeed, these two regions accounted for almost 90 percent of all transactions and about 94 percent of all investment commitments between 1990 and 1997. Both regions benefited from a tremendous boom in demand in the 1980s, a time when many investors believed that they could do no wrong in regions that had apparently learned to manage their macroeconomic problems and could take advantage of the eased borrowing terms allowed by top credit ratings and an excess supply of capital flows.

Transport investment in developing countries is skewed toward rail and road projects-just as it is in industrial countries-because public rail services tend to be equally inadequate in both country groups. Keeping rail and road transport costs under control is a major concern because of the significant expenditures required to rehabilitate the infrastructure and improve operational performance. As it becomes increasingly clear that both efficient logistics and the opportunity for multimodal arrangements are essential to competitiveness, governments are eager to upgrade rail services rather than continuing to rely on trucks for all long-distance freight transport. Additionally, cars impose congestion costs in and around large cities that can be substantially reduced by better modal combinations. Emerging economies are recording significantly more private activity in port infrastructure-again reflecting the need to address high costs.

These trends imply that private entrepreneurs will be responsible for an increased share of transport services. More than 30 percent of railway services-measured both in total kilometers and in passengers per kilometer-are now in the hands of the private sector around the world. The private sector increasingly owns and operates airports and seaports in the industrial countries (except for the United States), Latin America, and East Asia, but this is still a far cry from the typical situation. Even in 
the roads sector, where public funds will continue to be needed in rural areas that carry little traffic, private toll roads are meeting a growing share of traffic needs, particularly in Argentina, some parts of Brazil, and Chile. It is not too risky to predict that this trend toward private participation is likely to continue as the demand for new transport facilities continues to outpace the government's ability to raise the necessary resources. This is no longer the dogmatic "public versus private" debate heard after the Thatcher administration's privatization campaign in the United Kingdom. For many countries, private participation is a matter of necessity, as governments can no longer afford to be the sole operators and financiers of costly transport infrastructure.

Most governments have recently come to similar conclusions. About 73 percent of the projects shown in table 2 reached financial closure between 1995 and 1997. In fact, about 45 percent of the investment commitments were made after 1996. The table also indicates that time is needed to negotiate the contracts that support these projects, and both government and private operators must travel a steep learning curve to work with each other. Moreover, as the 1998-99 financial crisis showed, it is quite easy for the private sector to halt all contract negotiations when the surrounding macroeconomic environment is not supportive enough.

\section{The Effects of the 1998-99 Financial Crisis on Private Participation}

The financial crisis that began in East Asia in 1998 and spread to many other emerging financial markets in 1999 introduced constraints on private participation that are not reflected in the data shown here. Although recovery is on the horizon, conditions have changed, altering the nature of and prospects for private financing of transport activities in the next two to three years. Large portfolio outflows from emerging market funds mean that the sources of international equity and debt capital that became available in the mid-1990s have been sharply curtailed for all but the most creditworthy projects. The crisis has also influenced the demand for transport services: a slowdown in growth slows demand for transport as well. This contraction is a serious problem because experience suggests that even before the crisis the government teams charged with organizing privatizations tended to overestimate demand in the transport sector, probably more than in any other sector. What does this mean for the future?

The most obvious effect of this financial tension has been an increase in the level of risk. Premiums for commercial risk (driven by demand), regulatory risk (driven by institutional problems), political risk (always higher in uncertain times), and currency risk all rose significantly in 1999. Restrictions on financing options have also been 
damaging. First, the costs of financing debt have increased not only for most developing economies but also for some industrial countries in Asia. Depending on the particular project, a lending rate of LIBOR (the London interbank offered rate) plus 810 percent should not be unexpected in many developing countries, which means that only the very best projects are finding a market.

Moreover, lenders are requiring higher levels of equity for many projects. In Brazil, for instance, projects that were being structured with as much as 70 percent debt and 30 percent equity in mid-1998 were being discussed at a minimum of 50 percent debt and 50 percent equity by the end of 1999. Because of the rapid outflows from emerging market funds and from developing country infrastructure funds, project sponsors have found it difficult to tap these funds as sources of equity. Many governments in developing countries are looking at construction and engineering companies as potential sources of equity. The challenge is to offer an appropriate incentive for these parties to undertake construction of the infrastructure. When projects were financed with 70 percent debt, construction companies could justify putting in about half of the 30 percent equity. With up to 50 percent equity required, however, construction profits are not adequate to earn a satisfactory return. In fact, the higher interest rates on debt mean that even if the old capital structure mix could be maintained, construction company equity holders would still require a much greater ongoing revenue stream to make such projects viable.

Furthermore, the maturity period of permanent debt instruments is likely to shorten for many borrowers. In countries without domestic long-term capital markets, many transport concessions use bridge financing until the construction is completed; at that point, concessionaires expect to convert these loans to permanent financial structures. But stability concerns have tended to shorten many lenders' horizons to 5 years, compared with as long as 10 years before the crisis-a major problem for many infrastructure projects. Even with a grace period for construction, many projects take three to five years to reach operating volumes that are selfsupporting.

These problems suggest that governments need to redefine the ground rules for cofinancing the sector. Since the beginning of this new privatization wave, they have participated through implicit or explicit guarantees and have often picked up the tab in the form of subsidies when risks became realities and additional financing was needed. But now governments must consider providing explicit and transparent guarantees or contributing more equity to the projects. The Brazilian development bank has taken this route by buying some 21 percent of the shares of assets that were privatized.

In Latin America these actions can reduce the risk premiums by $2-4$ percent. This markdown may make projects more feasible, but it will not produce the required return on equity. The real value to government investment would be if the guarantees promoted both a higher share of debt and a lower required return on private equity. 
This does not appear to be the case under current capital market conditions. Rather, the discount serves to "buy down" the size of the project to make it more attractive to private capital.

\section{Preferences for Private Sector Participation in Transport}

Tables 1 and 2 provide an aggregate review of privatization activities in the transport sector. As noted earlier, privatization is a broad concept that hides many forms of private participation. Four broad categories of contractual arrangements for private participation are:

- Divestiture. The actual sale of public assets to the private sector can be accomplished through public offerings of shares or private sales of assets, and each of these can take many forms.

- Greenfield Projects. Under this approach the government commissions new investment projects, such as new airports, to a private owner (build-operatetransfer contracts are among the most common types). The development of new financing techniques that reduce or better allocate the risks of financing new infrastructure projects is one reason that greenfield projects have been so successful. It also explains why the specific design of unbundling the sector is so important.

- Operations and Maintenance (o\&M) Contracts. This option calls for a private operator to manage and maintain the service but does not include investment obligations. In other words, the operator assumes the risk of operating and maintaining the service, and the government retains the investment risk. These contracts are typically awarded for a given period (two to five years).

- Concession Contracts (or Franchises). In this case a longer-term contract (10-30 years) assigns responsibility for operations and maintenance to a private operator that also assumes investment and service obligations. Many governments prefer this approach to divestiture because it does not imply a politically sensitive transfer of ownership of public assets to the private sector; instead assets are rented out.

In the industrial countries, asset sales (particularly in Australia and continental northern Europe) and concessions or franchises (in the United Kingdom, southern Europe, and Canada) have dominated most of the business in transport. The relative importance of build-operate-transfer projects is likely to increase in the United Kingdom as a result of the Private Finance Initiative, which promotes public-private partnerships for infrastructure (Wilson 1999). In Australia, Canada, Germany, the United Kingdom, and the United States, even local governments are interested in this form

of infrastructure financing. Urban roads in Australia and the United Kingdom are 
increasingly being marketed through what are essentially design-build-financeoperate contracts. Under these deals, private sector contractors take a large share of the risk that would otherwise have to be assumed by the government and therefore face strong incentives to provide infrastructure that local taxpayers want and for which they will pay.

In developing and transition economies concessions are the most common form of private sector participation in transport, although greenfield projects have been quite successful in East Asia over the last 15 years (table 3). The recent financial crisis essentially froze most project finance activities in the developing world, resulting in the reallocation of financing flows to industrial countries. Canada, for example, recently signed with a private operator very creative toll-road financing design; such countries as Australia and Portugal that have strong political commitments to private sector participation are riding a wave of build-operate-transfer projects and concessions in transport.

Middle Eastern countries have been the least effective (or the least interested) in forging partnerships with the private sector, although port projects have seen some activity, and there has been a recent concession to finance and operate the Aqaba railway in Jordan. South Asia and Africa were similarly inactive, although Burkina Faso and Côte d'Ivoire did secure a successful binational railway concession with private investors. Part of the problem in these regions is that most types of riskcommercial, political, and regulatory - are high and the ability to pay for transport services is very modest. Thus, a sustained infrastructure program will require rather long-term commitments to recover investments.

There seems to be a strong hope for change in Africa and South Asia. Recent projects in Côte d'Ivoire may provide a glimpse of things to come: A concession contract for the airport was granted, a major toll road is now in the hands of a private construction company, and a commitment for a seaport concession is about to be granted. Similar stories can be told for at least a dozen African countries, indicating

Table 3. Types of Private Sector Involvement in Developing and Transition Economies, by Region (number of projects per contract type between 1990 and 1997)

\begin{tabular}{lcccccc}
\hline Project & Africa & East Asia & $\begin{array}{c}\text { Eastern } \\
\text { Europe }\end{array}$ & $\begin{array}{c}\text { Latin } \\
\text { America }\end{array}$ & $\begin{array}{c}\text { Middle } \\
\text { East }\end{array}$ & $\begin{array}{c}\text { South } \\
\text { Asia }\end{array}$ \\
\hline Divestiture & 0 & 8 & 5 & 6 & 0 & 0 \\
Greenfield projects & 1 & 49 & 1 & 8 & 2 & 6 \\
O\&M projects & 10 & 10 & 1 & 12 & 2 & 0 \\
Concession contracts & 3 & 83 & 4 & 140 & 1 & 8 \\
Total & 14 & 150 & 11 & 166 & 5 & 14 \\
\hline
\end{tabular}

Source: World Bank PPI database. 
that the market seems to have found ways to mitigate the risk and is now convinced that it can deal with the political and regulatory problems that are believed to be much higher in Africa than elsewhere.

From a sectoral perspective concession contracts have overwhelmingly been the preferred form of privatization for all sectors except ports (table 4). In this sector, which had the highest share of operation and maintenance projects, contracts were slightly dominated by greenfield projects. Some of the resistance to private entrepreneurs in this sector may reflect the strong role of unions, many of which are reluctant to give up the rents that their control of the sector often yields. A new approach is being tried in Brazil's port sector, where unions have traditionally been quite strong. Unions are now working with logistics companies to develop reforms to create new businesses that can absorb labor no longer required in traditional port activities.

Much of the data in table 4 is somewhat surprising. Private participation is comparatively low in the airport industry, even though it is generally viewed as a relatively low-risk industry with good long-term growth prospects. Growth in air traffic has been strong, and most experts agree that it will continue to be strong for the foreseeable future. One explanation may be that the military, which has had a strong say (and often a good financial cut) in this sector, tends to be reluctant to relinquish profit.

Nonetheless, divestiture is generally picking up in the airport sector. Even in Asia the growth in airport projects is quite obvious. Japan, the Republic of Korea, Malaysia, and Thailand plan new airports. Many airports in industrial countries are being offered as divestitures rather than concessions, a trend that may spread to developing countries. A new pattern is the growth in efforts to obtain private financing for relatively small airport projects (cargo facilities, catering facilities, and so on) to complement public financing of core structures. One indicator of this trend is that many investment banks are reorganizing their airport advisory units to support more divestiture activities in addition to project financing activities. Another trend is that current airport operators in Amsterdam, Frankfurt, London, Rome, and Toronto are

\begin{tabular}{|c|c|c|c|c|c|}
\hline Project & Airport & Port & Rail & Roads & Total \\
\hline Divestiture & 2 & 6 & 4 & 7 & 19 \\
\hline Greenfield projects & 5 & 32 & 6 & 24 & 67 \\
\hline O\&M projects & 3 & 21 & 4 & 7 & 35 \\
\hline Concession contracts & 15 & 31 & 23 & 170 & 239 \\
\hline Total & 25 & 90 & 37 & 208 & 360 \\
\hline
\end{tabular}


bidding for contracts in developing countries. Most U.S. and U.K. rail and port operators are involved in the key rail bids in developing countries as well. In the roads sector, it is difficult to find an example in which the main local construction companies are not involved. This is a natural development because in many cases these companies were hired by public works departments to build, operate, and maintain many of the roads. At the same time, such activity could also indicate collusion between the government and a private sector partner.

\section{How Competition Enters Transport Infrastructures}

Historically, the economic and political reasons for public interest in transport-scale economies, externalities, and national security - led most countries to rely on public enterprises or ministries to operate or control their transport sectors. The United States was the only country that chose to rely on regulated private provision. The academic debate on the potential gains from privatization was premised on a perceived need for more competition in the market. In the United States, where deregulation of the transportation sector began in the late 1970s, increased competition meant lifting restrictions on entry (such as licenses) and operating rights as well as eliminating strict price and quality controls. The benefits of liberalizing the sector appeared to be quite obvious, not only to economists but also to the public. Support for private participation was based on the static and dynamic efficiency gains expected from increased competition (lower costs, fewer price-driven distortions, better user service, demand-driven investment) and was well publicized in the United States through extensive media coverage. But the United States may be an outlier and therefore less relevant than more recent experiences elsewhere. Indeed, in the rest of the world, all transport infrastructure tended to be run by strong public monopolies. In those countries where fiscal rationing prevented government from undertaking new transport projects, it was clear that there could be no liberalization without some type of restructuring in the sector. In that sense the reform experiences in such countries as Chile and the United Kingdom are more representative than is the U.S. experience.

Thus, the first question that must be answered any reformer aiming at increased competition in transport is how much restructuring is needed to make the most of the opportunities offered by a reasonable degree of competition in the sector. In practice, restructuring generally implies some degree of unbundling of the activities performed in each subsector. This is much more than a simple accounting separation; the monopoly must be dissolved into various business units. The restructuring can be horizontal, so that the effectiveness of various companies delivering similar activities can be compared (common in airports, ports, and railways), or vertical, so that a single firm can participate in different related stages of production. Vertical unbundling is often handy in reducing risk because the levels of risk for potential investors 
are different at each stage of production. For instance, investing in an airport terminal is less risky than investing in a new runway, although the two investments have a clear degree of complementarity. In addition, unbundling either horizontally or vertically offers political advantages. It can be a way of getting rid of vested interests and introducing a new governance structure that reinforces the purely competitive and commercial incentives for seeking private participation in the first place.

When unbundling leads to competitive business units in overlapping segments of the business (as may be the case for bus services), the government's role becomes one of safeguarding the public's interest by monitoring safety, environmental concerns, and predatory behavior. In some cases competition in the market is limited; that is, there is little scope for horizontal unbundling, and the market structure retains a local monopoly even after the unbundling has been implemented. In this situation competition for the market through a government-sponsored auction can achieve many (but seldom all) of the gains from competition. Managing such auctions is quite complex and demanding; the outcome requires a strong government presence to ensure that the winners of the auctions meet their promised commitments and that the gains from competition are real rather than potential. Transparency is also essential to ensure that the award of the concessions is not marred by corruption.

\section{Unbundling to Ensure Competition}

Attracting private entrepreneurs to finance what the government can no longer afford to finance is the name of the game; therefore, the method that is used to unbundle the sector is extremely important. Experience shows that the transport pie can be sliced in many ways. Indeed, the type and degree of competition achieved by unbundling depends not only on the classical tradeoff between internal efficiency (the relative choice of inputs) and external efficiency (sales and pricing policies) but also on the level of risk perceived by potential private operators. Where economies of scale are not too strong relative to the size of the market, unbundling can reduce the aggregate commercial risk level perceived by private investors. Competition for the market in each activity can be sufficient to promote overall efficiency. Unbundling should stop at the level of activity that requires some type of material infrastructure (rail tracks, roads) that would make no sense to duplicate in a competitive environment. Moreover, too much unbundling can be harmful if it reduces the opportunity to hedge risk across activities in highly risky situations or to optimize economies of scale and scope. This may be why much less unbundling has taken place in smaller economies in Africa and Central America than in South America and East Asia.

An overview of the various sectoral experiences shows the creativity of the reformers; see Estache and de Rus (2000) or the papers by Juhel (1998) and Thompson and Budin (1998). Railway services can be unbundled vertically, by separating track from rolling stock, as in the United Kingdom, or horizontally, by establishing regional lines, 
as in Argentina, Mexico, and the United States. Both types of unbundling permit firms to compete for the market. Bidding out the rights to deliver the services also creates an opportunity for competition between markets. No country-except the United States and, to a lesser extent, Australia — has actually made a serious effort to compare regional operators in terms of efficiency. Argentina and Brazil have taken a different tack, also separating freight and passenger rail to minimize the risks of crosssubsidies that distort investment decisions.

Similar strategies apply to roads, where horizontal separation forces operators to compete in different markets, enhancing the effects of competition for the markets by giving regulators enough information to compare the performances of the various local monopolies. This horizontal separation into corridors has been quite common in Latin America. Competition has been stimulated by vertical separation both in Latin America and in Asia through auctions that award separate contracts for access roads to interurban routes. A less familiar practice entails auctioning operations and management contracts to the private sector to minimize road maintenance costs and avoid demanding investments in equipment. This practice is quite common in Latin America and is picking up steam in the other parts of the world. Unbundling regional units of a business also allows the introduction of competition between markets by comparing the performance of the same types of service in different regions of the country.

The promotion of interregional competition among ports (as in Brazil and Chile) and of competition among terminals within ports (in Argentina and, to a lesser extent, Brazil) allows comparison of the performance of the winners in the various segments of the sector over time. In some countries, such as Sri Lanka and Peru, vertical separation between infrastructure and port services has been the most desirable solution.

Finally, for airports, horizontal separation across regions (as in Mexico) and vertical unbundling of air traffic control, terminals, runways, and passenger and commercial services are common (Canada and Colombia, for example). This experience shows that airports do not have to be treated as single, monolithic monopolies. It is also clear that interregional competition does work, as operators are sensitive to the potential competition from other operators in their area.

\section{Multiple Objectives for Restructuring}

Governments contemplating a restructuring of their transport sector generally seek to fulfill several objectives, including short- and long-term efficiency gains as well as fiscal goals (Crampes and Estache 1998). The relative importance of each objective has a strong influence on the type of restructuring that is adopted. In this respect, Argentina's first wholesale reform of the transport sector in the 1990s is quite revealing. This major restructuring, initiated in 1991 as part of a wider privatization and deregulation 
strategy, was a precursor for transport sector reforms in other developing countries. Specifically, it showcased the complex interactions required to achieve efficiency gains and at the same time address the government's macroeconomic objectives. The most important of these objectives was to reduce subsidies to a sector traditionally funded by public financing while also keeping fares low enough to meet the needs of the poor. The outcome achieved the desired efficiency gains, but the sector continues to be heavily subsidized (although much less so than before the reforms). After difficult negotiations many of the rail and roads operators were awarded longer-term contracts than anyone initially thought would be required to minimize the subsidy requirements.

The dilemmas governments face in restructuring can best be understood by looking at the various ways that unbundling can address their fiscal concerns. First, governments can sell or rent assets to the private sector. Second, they can pass on the financing costs of operating and investing to private operators; this approach shifts the costs from the taxpayer to the user, which is quite important because many publicly operated services tend to be underpriced or subsidized. Third, governments can subject private operators to the standard tax regime rather than formally or informally exempting them, as is often the case for public enterprises. Most reforming governments with serious fiscal constraints prefer the first option. Governments have also recognized that it is profitable to privatize services that demand huge subsidies because private operators can often cut subsidy costs quite quickly. Even where subsidies are still needed, they can be obtained at a lower fiscal cost. This is the case for many railway services in Argentina, Brazil, and the United Kingdom.

Governments may also have to deal with the temptation that private investors may have to play perverse games that are not necessarily in the interest of consumers. Private investors may attempt to minimize service obligations that would benefit the poor but would increase commercial risk, for example, or they may try to shift as much risk as possible to the government and the user. The government may end up going along because of its commitment to restructuring. This situation automatically creates a tradeoff for the government. Indeed, the greater the retained degree of monopoly passed on by the government, the more willing private operators are to pay for the right to run a service. This means that the initial desire to liberalize to achieve efficiency gains may give way to the need to meet pressing fiscal needs. In the telecommunications sector, where temporary exclusivity periods are quite common, the evidence is quite strong that the high fees paid for concession licenses are financed by the rent that private monopolies capture from their customers. The rent is typically not as high in transport, where competition between modes of transport maintains pressure on the rent, thereby reducing the willingness of customers to pay excessively high prices for former public services. But for some airports and for ports with little competition in some market segments, this is an issue.

Recent experience in the airport sector points to another way that restructuring and fiscal concerns interact. In many countries, airports often benefit from cross- 
subsidies financed through international traffic or through high-demand domestic airports. When restructuring the sector, privatization teams often recommend maintaining the cross-subsidies and selling or using concessions to operate airport packages (typically one major airport and a few local ones) rather than individual airports. The intention is to minimize the need for the government to record losses on airport activities, even if it pays out explicit subsidies. This debate is under way throughout Latin America, from Argentina to Mexico.

The incentive for governments to condone, even temporarily, some restrictions on competition is in fact quite common. Indeed, the government can use airports, ports, and railways with strong captive-client bases or with shared traffic to achieve high fiscal gains. This is why the pricing of the right to access on infrastructure owned and operated by a competitor is a key issue - and great business for consultants - in this sector. Unless access pricing rules are defined before the business is passed on to private operators, rents are being created that are clearly harmful to users. Long an issue in the United States, these harmful rents have become an issue in the United Kingdom and are proving to be a problem in most developing and transition economies, where the need to transfer the business to private operators is often so pressing that there is little time to work out the demanding details of access pricing.

The multiplicity of government objectives also explains the variation in award criteria for contracts. Governments that are concerned about users and that want to make the gains obtained through privatization more transparent will generally opt for awarding the concessions to the bidder that charges the lowest tariff. This is quite common for toll road or port contracts. Some governments with political concerns will award the contract to the bidder that offers to run the business for the shortest duration. This was the case for some toll roads in Mexico. An alternative is to award the concession to the bidder asking for the shortest time to recover the investment, as was the case for toll roads in Chile.

When fiscal concerns dominate, the concession can be awarded to the bidder willing to pay the most for the right to provide the service. Where demand for the service is not strong (such as low-traffic roads), obtaining the best fiscal outcome may mean picking the bidder that asks for the smallest subsidy. These examples show that the choice depends on the weights governments attach to their multiple goals. These weights are likely to vary over time as political concerns change.

\section{The Role of Government after Privatization}

Privatization requires a government to make numerous decisions about its priorities, the forms of competition it wants to promote, and the type of unbundling that will best meet its goals. Once those challenges are resolved, the government's role becomes one of monitoring compliance with and enforcement of the contractual commitments 
made by the private operators. Thus, governments that privatize must also make several decisions involving their role in and capacity for regulating the conduct of the private participants.

\section{Defining the Role of Economic Regulation}

Once the contracts have been awarded, the government should intervene only to ensure that competition works and to check on safety and environmental concerns. If the government does not have the capacity to enforce economic regulation of the sector, it must develop the ability to make regulatory decisions that mimic the impact that competition would have had in the sector if it had been possible. Government intervention will be needed if:

- High legal barriers inherited from past regulatory regimes need to be sorted out (Kennedy 1997; Laffont and Tirole 1998; Valletti and Estache 1999).

- The privatized services are natural monopolies that might result in abusive pricing, harm to captive shippers (those that have no alternative for moving their goods), or harm to consumers from investment-related issues, such as access pricing.

- Predatory pricing takes place.

- Safety cutbacks are present.

An effective competition or antitrust agency can take care of the first three responsibilities (Kahn 1998). If no such agency exists, these concerns can be included in the mandate of the economic regulators. These are not the only responsibilities of these regulators. In addition, they need to monitor compliance and enforce the contractual commitments - investment, quality, safety, and service obligations-of the private operators.

\section{Choosing the Appropriate Economic Regulatory Regime}

In large measure economic regulators try to balance a fair price to consumers against reasonable returns to the operators. Traditionally, governments have relied on rateof-return regulation, under which they guarantee that operators will recover their costs (within very general, often generous, guidelines) and make enough money to remunerate investors - thus the label "cost-plus" regime. Under these regimes operators do not have a strong incentive to cut costs, so government regulators have introduced price caps to show that the regulatory regime could be designed to minimize costs. Price caps allow operators to keep the cost savings they realize for the first three to five years. After that time any savings have to be shared with the other agents (users and sometimes governments). The high incentive to cut costs for the initial period makes this a desirable adjustment for operators and consumers. Many coun- 
tries, including Argentina and Mexico, have designed hybrid systems that result in some degree of immediate rent-sharing at the beginning of private sector operations.

An often overlooked feature of the regulatory regime is that it also drives the distribution of risk in the business (Alexander, Estache, and Oliveri 2000). Cost-plus regimes entail little risk because cost recovery is almost guaranteed whatever the demand. Price-cap regimes, in contrast, shift all the risk onto the private sector. This is relevant to the extent that it influences the total level of risk faced by potential investors. In situations where the initial risk is very high, this choice can make or break a deal. In practice, of course, things are not always so clear-cut. Regulators of cost-plus regimes can disallow expenses they consider to be unnecessary, excessive, or inappropriate; that ability allows some degree of arbitrariness in the decisions. At the same time, simple price caps may lead operators to cut costs by reducing quality or disregarding safety. Moreover, the measurement of the efficiency gains that must be shared with users after the contract period expires can generate serious political conflicts, as happened in the United Kingdom.

\section{Developing the Institutional Capacity to Regulate}

The introduction of more sophisticated regulatory regimes has made it clear that countries need to develop a regulatory capacity. In practice, such entities face two main risks. The first is the possibility that operators will control the regulators and that the government will be lenient in the event of conflict. The second is the risk that users or customers will control the regulators and will impose demands that are not covered by the contract. There is also a risk that the government will not deliver on its own contractual commitments, which increases the operator's perception that the risk of expropriation exists. Sometimes subsidies are part of the commitments (usually implicitly, because risk assignment is typically built into the design of the regulatory regime). For instance, when reviewing tariffs, decisions involve such issues as cost allocation or the calculation of the cost of capital. These issues clearly influence the allocation of risk, profit, and rents among the operators, investors, users, and the government, and all of them can give the appearance of a conflict of interest.

Delivering on government commitments is a challenging task, as experience shows. Because contracts and the other supporting regulatory legal instruments are often incomplete, the government must be able to demonstrate fairness in settling issues and disputes that the legal instruments do not cover in detail. The restructuring of the sector should include a commitment device that guarantees fairness. The most common device is the creation of an independent regulatory authority, free from the control of politicians, the government, operators, or users of the service. Clearly, this authority must be both financially autonomous and accountable for its decisions (Broadley and Estache 1998). 
Most countries still have a long way to go in developing adequate regulatory capacity. The oldest experience with an independent, integrated regulation of the transport sector is that of the Surface Transportation Board in the United States. Its principal strength is that it operates in a relatively transparent and accountable environment where all interested parties have an opportunity to present their views at all levels - before Congress, before the agencies, and before the courts. The process of judicial review generally ensures that the regulatory agency applies the regulatory law as intended by Congress and that the agency makes decisions based on evidence. The main weakness of the system is that it imposes very high compliance costs. This has proven to be very difficult to change in this sector, where there is a significant interest in the status quo.

The sad fact is that there is no good news to report on experiences with new regulatory regimes. Although regulatory processes in the United Kingdom have much that deserve emulation, the institutional design for regulation is probably not a model to follow. The United Kingdom has more regulatory agencies than it has transport sectors to regulate. In fact, the government is in the process of merging some of the agencies to ease the coordination of regulatory decisions. In most countries the solution has been to create units within the Ministry of Transport to monitor concessions or other contracts with private operators. The main disadvantage is that in the case of disagreement with the government, conflicts of interest emerge quite quickly. Various experiences in Latin America suggest that the lack of transparency in the decisionmaking by these monitoring units often creates tensions that are well reported by the press. Such disputes then become fodder for political debates about the privatization process - debates based on few facts and many rumors.

To minimize the excessive politicization of regulatory issues, a new generation of transport agencies is being introduced in Latin America, inspired by the integrated U.S. model and led by Bolivia and Peru. Both countries have regulatory agencies that are much more independent of policymakers and political influence than they were in the past. The agencies cover all transport sectors and have their own sources of funding - typically a "regulatory fee" paid by the operators. They also rely on this funding to subcontract activities that they do not have the skills to perform in house. In addition, Peru has built in an interesting twist. To ensure good coordination between the competition agency and the transport regulator, one of the members of the Transport Regulation Board is also a member of the Competition Commission. Although very promising and clearly an improvement over previous arrangements, the experience with these models is still too limited to lead to any conclusion. The challenge remains, however, and continues to be the biggest source of long-run risk to the success of privatization. An incompetent or controlled regulator is the best indicator that the outcome of privatization will be unfair. Previous experience shows that when contracts are poorly designed, any unfairness in them tends to favor the investors and operators rather than the users. 


\section{Developing the Tools of Regulation}

This point brings up a second aspect of institution building that is needed for fair and effective regulation. Experience with the first generation of privatization suggests that without good tools, even a good regulator can be a source of conflict and unfairness. For all practical purposes, the main instrument of a regulator is the contract signed with the private operator. The tough question is this regard is to decide how much discretion to give the regulators in interpreting the contract (Gomez-Ibanez 1999). The larger the degree of discretion desired, the less detailed the contract will have to be, as the regulatory decisions will be based on laws or decrees that have to be interpreted by the regulators. The smaller the degree of discretion desired, the more detailed the contract will have to be, thus increasing the relative importance of contracts in the design of the regulatory environment. Because not all events can be foreseen-meaning the contract can never be complete - there will always be a residual degree of discretion. This means that the government will have to have a strong technical capacity to make right and fair decisions.

Generally, weak regulators have been given too much discretion without enough guidance to make good decisions on matters left out of the contracts. In developing countries the combination of weak regulators and poor contracts has resulted in the renegotiation of an extremely large percentage of contracts. The losers in these renegotiations have usually been the taxpayers, as governments often end up picking up the tab for the financial consequences of renegotiations.

An increasingly popular solution is to work with rule-based contracts because they tend to make regulation easier in the face of overwhelming uncertainty. The challenge is to pick rules that are fair and have minimal information requirements-one of the advantages of price cap regulation. In addition to their incentive structure, price caps have the tremendous advantage of having very light information requirements, at least when they are introduced. Five years down the road, when the caps have to be revised, the information load is similar to rate-of-return regulation. Rules make it easier for arbitration, when necessary, to be efficient. But here again, the concern is with the fairness of local arbitrators. Most infrastructure contracts written since 1998 have identified one of the international arbitration agencies as the appeal agency in case of conflict.

Rule-based contracts cannot cover every contingency, however, so regulators everywhere need to build up capacity in other areas. A common failure of privatization experiences in industrial, developing, and transition economies alike is the failure of governments to assess demand accurately. The two most common reasons private operators give for asking for a revision of their contracts are cost shocks and demand far different from predicted. That is because the public enterprises that were running the services before privatization had no incentive to be concerned with demand. 
A more cynical interpretation is that governments and operators both have perverse incentives not to press initially for accurate information on demand. The government often wants to make business look better than it is because it wants to get the deal done. It bets that problems, if they emerge, will be far enough in the future that they will become the responsibility of the next government. The potential operators, for their part, actually know that they stand a good chance of going back to the government to negotiate better terms once they have started service. At that time, the transaction costs (including the political costs) for the government of canceling a contract without renegotiation are generally much higher than the costs of giving up some ground by accepting some of the demands made by the incumbent operator. Often the government gives up too much in an effort to resolve the conflict quickly. This raises the stakes for demands by private operators in the following round of privatization or renegotiations and possibly increases the incentive to renegotiate. Although this process may cut the regulatory risk premium, as operators become convinced that they can do business with the government, it may also mean that users or taxpayers end up paying the bills that result from renegotiations. Note that governments can rarely play hard ball because the operators can simply halt all operations and the users will be stranded.

A final problem common to all country types is the difficulty of designing access rules. Legal battles between operators needing access to infrastructure owned by other operators and these owners are the standard outcome of imperfect access rules. Railway regulators in Argentina, Brazil, France, and Spain are facing this problem. Similarly, in many countries safety is an issue that contracts do not address satisfactorily - a result of the risk of micromanagement if too much is said about it. Often the institutional assignment of responsibility for safety issues is not clear and may, in fact, be a symptom of another institutional problem. In addition to the multiplicity of agencies responsible for the economic regulation of transport, many other agencies typically are involved in enforcing some type of noneconomic regulation. Environmental regulation is common, but local land-use rules often conflict with contractual obligations as well. The point is that few countries are able to involve all the interested agencies in effective regulation strategies. The results instead show up as coordination problems, for which every agency blames the other. Finally, few countries have escaped some type of collusion, either actual or potential, between construction companies and the government, or among other potential members of consortiums that are interested in taking over a transport infrastructure project.

\section{Conclusion}

It is clear that the private sector will not be the main source of financing for every transport project. Highways and roads, for instance, are likely to continue to require 
significant public funding. Even so, innovative ways to attract private financing for maintenance and investment needs (such as shadow tolls, where the government uses general tax revenue to reimburse operators costs based on the volume of traffic) may increase the cost-effectiveness of the sector. In fact, the experience of the 1990s suggests that private sector involvement in transport is expanding investment and cutting public sector financing requirements (Winston 1993). It shows that reforming governments can be quite creative in tapping this potential, as illustrated by the variety of restructuring models and financing designs that have been adopted across sectors and countries.

Many observers would also argue that the effectiveness of this public-private partnership in transport infrastructure has tended to improve quite dramatically with the introduction of competitive practices in the sector. This move suggests that the longterm prospects for increased private participation in transport, particularly in airports and ports, are encouraging.

The transport sector could attract additional competitive private capital if governments could improve their regulatory tools and sort out the institutional mess surrounding the regulatory process; the latter may be the biggest problem facing reformers. Knowing the cost of capital, knowing how to be fair to captive shippers, and having a better handle on demand will give regulators more credibility when conflicts arise. Governments have been too focused on getting deals done and not enough on their new job as regulators. Although they increasingly are switching to contractbased regulation to firm up the commitments of all parties involved, they are not putting enough emphasis on designing the contracts to anticipate conflicts and address unpredictable situations - an omission that increases the risk of arbitrary regulatory rulings. This, in turn, has increased the regulatory and political risks, raised the required expected rate of return for potential investors, and made future projects more difficult and more expensive; it has also exacerbated the effects of the 1998-99 financial crisis.

Increased risk has resulted in a self-selection bias in the type of potential entrants into the sector. The two main groups are, first, the large, strong operators in the sector-typically in tandem with local construction companies - that are confident they will be able to take on the regulators in case of conflict, and, second, newcomers that have to take some risks to penetrate the market. Either way, the taxpayers and the users are the most exposed to government, regulatory or operator failures that result in contract renegotiations. These seem to be the norm rather than the exception in infrastructure projects.

In short, there is a risk that the gains from privatization will not reach the people simply because governments are ignoring the importance of their responsibility for the fair distribution of the long-run gains through the early creation of independent and accountable regulatory institutions that work closely with effective competition agencies. Learning to regulate fairly and effectively at arm's length may be the main 
challenge for governments in the next millennium. Those governments that are unwilling to take steps to meet this challenge may prevent users from making the most of the additional investments made by the private sector.

\section{Notes}

Antonio Estache is lead economist for the Governance and Finance Division of the World Bank Institute. The author would like to thank Ofelia Betancor, Javier Campos, Jose Carbajo, Newton De Castro, Gines de Rus, Jose A. Gomez-Ibanez, Kenneth M. Gwilliam, Marc H. Juhel, Jean-Jacques Laffont, Gustavo Nombela, John Strong, Lewis Thompson, and Lourdes Trujillo, and three anonymous reviewers for suggestions on many of the issues covered in this paper.

1. A billion is one thousand million.

\section{References}

The word "processed" describes informally reproduced works that may not be commonly available through library systems.

Alexander, Ian, Antonio Estache, and Adele Oliveri. 2000. "A Few Things Transport Regulators Need to Know about Risks.” Utilities Policy 9(1):1-13.

Broadley, John, and Antonio Estache. 1998. “Transport Regulation, Institutions, and Processes.” World Bank Institute, Governance and Finance Division, Washington, D.C. Processed.

Crampes, Claude, and Antonio Estache. 1998. "Regulatory Trade-Offs in the Design of Concession Contracts." Utilities Policy 7:1-13.

Estache, Antonio, and Gines de Rus, eds. 2000. Privatization and Regulation of Transport Infrastructure: Guidelines for Policymakers and Regulators. Washington, D.C.: World Bank Institute Development Studies.

Gomez-Ibanez, Jose A. 1999. "Commitment and Flexibility: Strategies for Regulating Privatized Infrastructure.” Discussion Paper, Harvard University, Kennedy School of Government, Taubman Center for State and Local Government, Cambridge, Mass. Processed.

Juhel, Marc. 1998. "Government Regulation of Port Activities: What Balance between Public and Private Ports.” World Bank, Transport, Water, Urban Technical Development, Washington, D.C. Processed.

Kahn, Alfred E. 1998. Letting Go: Deregulating the Process of Deregulation, or: Temptation of the Kleptocrats and the Political Economy of Regulatory Disingenuousness. East Lansing, Mich.: Institute of Public Utilities and Network Industries, Eli Broad Graduate School of Management, Michigan State University.

Kennedy, David. 1997. "Regulating Access of the Railways Network." Utilities Policy 6(1):57-65.

Laffont, Jean-Jacques, and Jean Tirole. 1998."Network Competition: I, Overview and Nondiscriminatory Pricing; II, Discriminatory Pricing.” Rand Journal of Economics 29:1-56.

Public Works Financing International. 1999. “1999 International Major Projects Survey.” Public Works Financing October.

Thompson, Louis S., and Karim Budin. 1998. "Railway Concessions: Progress to Date.” Rail International (January/February):60-73. 
Valletti, Tommaso, and Antonio Estache. 1999. "The Theory of Access Pricing: An Overview for Infrastructure Regulators.” World Bank Working Paper 2097. Washington, D.C.

Wilson, Tim. 1999. “The Private Finance Initiative.” Infrastructure Journal (Winter):35-43.

Winston, Clifford. 1993. "Economic Deregulation: Days of Reckoning for Microeconomists.” Journal of Economic Literature 31:1263-89. 